\title{
The United Nations and Its Duty to Implement International Protection: Studying Different Situations in Three Different Continents
}

\author{
Etaf Abdel Qader Saafin ${ }^{1}$ \\ ${ }^{1}$ Politics and International Relations, Applied Science University, Amman, Jordan \\ Correspondence: Etaf Abdel Qader Saafin, Politics and International Relations, Applied Science University, \\ Amman, Jordan. E-mail: etafsafin@gmail.com
}

Received: March 17, 2019

Accepted: April 22, $2019 \quad$ Online Published: May 30, 2019

doi:10.5539/jpl.v12n2p34

URL: https://doi.org/10.5539/jpl.v12n2p34

\begin{abstract}
The paper aims to investigate the role of UN through its human intervention to solve the national issues to save the human life from genocide, ethnic cleansing, war crimes practiced by some states against their own citizens. To achieve its aim, the study used the historical and descriptive approach to analyze data of three case studies; Syrian crisis, Somalian crisis, and Kosovo's crisis, in which the states practiced Methods of repression and torture against their peoples to the extent that they needed essential intervention by the international community to stop the criminal massacres. Through the analysis of study it has been concluded that the UN does not apply human intervention principles to all states properly, and it is still affected by some powerful authorities. Finally, the study recommended that UN need to rethink its strategies that can enable human intervention be applied consistently and to all states their population suffer from disasters.
\end{abstract}

Keywords: humanitarian intervention, UN security council, disasters, Syria, Somalia, Kosovo

\section{Introduction}

After the World War II, a fledging institution called the united nations (UN) was immediately established aiming to save next generations from the war scourge, and over 40 years during the Cold War, the peace keeping forces of UN played an important role by reinforcing cease-fire agreements, separating the conflicting parties, and supervising elections.

Following the end of the Cold War, the UN Security Council issued numerous resolutions, based on Chapter VII of the Charter, concerning the settlement of issues that were not traditional among the sources of the threat to international peace and security (Burckle, 2018). Since the end of the cold war, humanitarian intervention, and sometimes, military intervention were necessarily emerged to save victims by preventing or stopping violence (Bertschinger, 2016).

the broad interpretation taken by the Security Council for the concept of the threat of international peace and security, which includes internal armed conflicts that are defined as serious violations of human rights, has become a legitimate justification for humanitarian intervention by the United Nations under Chapter VII of the Charter. This insistent responsibility had been clearly claimed by previous President of the Security Council " Annan, 2002", when he claimed "Responsibility to protect" civilians from Massacres, genocide, displacement and ethnic cleansing practiced by their states against humanity, meaning that it is the world' s responsibility to interfere in another state's territory for the purpose of protecting citizens from suffering (Damboeck, 2012).This insistent humanitarian intervention was recurred in some Arab countries allowed through the decisions issued by the Security Council under Chapter VII of the Charter. Such these conflicts have resulted in great violations of human rights and minorities.

The principle of " responsibility to protect " is a clear criterion in international law ratified by the UN Security Council and a qualitative shift in the way international law deals with humanitarian crises. According to the principle of "responsibility to protect", sovereignty is no longer absolute, but the State renounces its sovereignty when it fails to protect civilians from genocide, ethnic cleansing, war crimes, that are perpetrated against humanity, then the "responsibility to protect" of civilians lies with the international community (Wheeler, 2001). 
Cavandoli and Odello (2011) expressed that national state sovereignty in "responsibility to protect" is concerned with responsibility rather than control or power. Therefore, to be more comprehensible, state sovereignty was redefined by the commission as a something that cannot be absolute; rather it is internally organized by constitutional power that does share arrangements (Damboeck, 2012). Thus, the main argument is that, to maintain its state sovereignty, the state authority must fulfil three main responsibilities: it must protect the safety and welfare of its citizens, second, it must be accountable for its citizens internally and externally beside the principles laid in UN charter, and third, the state's agents have accountability of their actions (ICISS, 2001). If the state's authority has not potential to bear these responsibilities, it will lose its sovereignty.

Although the main aim of humanitarian intervention is to save lives, International Commission on Intervention and State Sovereignty (ICISS) did not specifically quantify the number of deaths according to which the military intervention should be triggered. The closest estimate described by the commission is "large-scale loss of life" or "large-scale ethnic cleansing" (ICISS, 2001, p. 32). With at least one of those two conditions, the criterion "just cause" can be satisfied.

Despite the main purpose of humanitarian intervention is to realize the human justice through preventing and refuting the persecution as well as oppression worldwide, and for that purpose its principles were emerged, it can be noticed that during its history since it had been established, United Nations, represented by the security Council behaved in flounder and unbalanced situations in some cases (Tufekci, 2018). This means that UN dealt with many political situations throughout the world in inconsistency.

This paper will analyze the UN attitudes of some crises that occurred in some states to explain how it tried to treat these crises in a different and inconsistent manner. To achieve this aim, three crises were taken in this study's consideration, which are Syrian crisis, Somalian crisis, and Kosovo's crisis, and based on this analysis, a set of recommendations has been provided.

\section{Theoretical background}

Human intervention, a concept deeply rooted in human's history, developed in its meaning and content through several generations and adapted to suit each generation in a specific era. Still today, humanitarian intervention has been related to intervene in a state where civilians live under wars and disasters. However, between imbalance of its principles and measures through its interventions, united nations (UN) which has the responsibility to protect people who are oppressed and afflicted, attracted attention of scholars of international law and policy to investigate and analyze UN principles and strategies to address the malfunction positions, and hence provide their suggestions and recommendations for purpose of enhancing UN performance of humanitarian intervention.

\subsection{The Concept of Humanitarian Intervention and "Responsibility to Protect"}

Humanitarian intervention is an old phenomenon in the history of international relations. Gisslen (2018) Mentioned that humanitarian intervention is a term that was first issued in $19^{\text {th }}$ century. He added that ancestral concept of humanitarian intervention is traced all the back to many hundred years B.C. The first international treaties known in the history of mankind date back to 1978 B.C Between Ramses II and King of Hittites, which emphasized the historical dimension of this phenomenon and the moral and human reality governing international relations (Gary, 2008). It also aimed to sanctify and protect human life in times of peace and war.

Foley (2013) contradicted the concept of humanitarian intervention argued by many scholars who confirmed that humanitarian intervention is insistent to save human life in case of state's persecution and oppression, when he mentioned that humanitarian intervention is no longer a principle agreed upon by international jurisprudence because of the criticism against it as a result of its conflict with the principle of non-interference in the internal affairs of States on the one hand and its use as a pretext for exploitation and colonization of States on the other. However, international jurisprudence differed in defining the concept of humanitarian intervention by two directions; the first direction accepts that humanitarian intervention cannot be done through military action and the use of armed force, but the second one advocates a broad concept of humanitarian intervention where it believes that intervention can be carried out by the use of military force and sometimes by other means such as political, economic, diplomatic and other pressures (Kent, 2014).

The principle of humanitarian intervention in the internal affairs of state is a fundamental principle of contemporary international law. However, the broad interpretation of Chapter VII of the Charter and the consequent expansion of sources of international peace and security have made it very possible to overcome this principle at present, and the humanitarian intervention has become a customary rule imposed by the Contemporary changes of international community (Tufekci, 2018). 
Seybolt (2008) Mentioned that massacres resulted from wars, such as those occurred in Sudan, Lebanon, and Darfur seized the attention of the world with harrowing stories of political complexity as well as huge size of human suffering. Some other disasters, such as those occurred in Democratic Republic of the Congo and northern Uganda, were ignored because they were faraway of media broadcast (Television, Radio, Newspaper, etc). The neglected atrocities caused a large scale on loss of life, instable economic and deteriorated political situations (Seybolt, 2008). Such these catastrophes led the international community to be undergone some embarrassing questions, such as what can be done to help ordinary citizens who are exposed to the conflicting groups or their states' oppression?, and how can we save them against starvation, killing, and stampede?. The argument about when and who outsiders that should be involved in the protection led to the concept of “'responsibility to protect' affected people. This controversial idea puts a huge onus on the UN members to protect the affected people when their states do not provide enough protection to them.

As response to the failure of the international community to avert humanitarian tragedies in both Rwanda and Balkans during the 1990s, the Canadian Prime Minister, John Cretian in 2000 called for the concept of "responsibility to protect" at the Millennium Conference to establish an international commission concerned with intervention and sovereignty (ICISS, 2001). The conference mission would be to support a global debate based on reconciling the duty of intervention of the international community against wide violations of humanitarian norms and the need to respect the sovereignty of States. In 2001, the Commission concluded with a report on "Responsibility to protect" (Flott, 2008). Additionally, According to the Official Records of the General Assembly (2012), the World Summit conference in 2005 also adopted the concept of the "responsibility to protect" populations from genocide, war crimes, ethnic cleansing and crimes against humanity. Further, in 2009, the General Assembly, in its resolution 63/308, agreed to continue consideration of this concept.

Today, "Responsibility to protect" is a concept that is composed of several fundamental principles included in international humanitarian law, international refugee law, and international human rights law. The implementation of this concept involves a wide range of instruments, techniques and partners (Janzekovic \& Silander, 2013). These fundamental principles, from the outset, have taken a narrow but in-depth approach. It is narrow in terms of its exclusive application to the crimes and violations referred to in paragraph 138 of the 2005 World Summit Outcome, and in-depth in terms of the variety of Charter-based instruments available for that purpose (Fontane \& Geslin, 2008).

\subsection{The Role of UN in Humanitarian Intervention}

The United Nations has had a major role to play in intervening to resolve several crises at the global level:

\subsubsection{First, Syrian Crisis}

\section{a. Syrian revolution in 2011}

The Syrian revolution started on March 15, 2011, and did not go beyond the beginning of the popular protests and peaceful uprisings, like other revolutions of the Arab Spring. The beginning was in the city of Dara'a to face repression and suppression of public freedoms, especially when the Syrian security forces extended the arrest, torture of children, and the killing of young people and elders, reason that spurred these peaceful protests to turn into a popular revolution that called to political, economic and social reforms and gradually extended to most Syrian cities (Joseph, 2011). However, the position of the Arab and international regimes differed on this revolution despite the corroboration and solidarity of the Arab peoples.

Tokmajyan (2015) Explains why Syrian revolution in 2011, has changed its peaceful direction and inclined to be violent. He argued that the violence is not preferable to people, but when nonviolence becomes distrusted because of its achievements have not been met by regimes, the masses believe that violence will be more effective to achieve their objectives. However, this is not always right to come consistent with the protests' perspective. For instance, in Syria, the international community was confident that President Bashar Al-Assad's would be changed through few months of Syrian revolution, and rather he is still the power, the Syrian revolution has been conquered, and Syria has been destroyed.

b. The "responsibility to protect" and its implementation in Syria

The principle of "responsibility to protect" emerged as a reaction to the failure of the international community to avoid committing crimes, genocide against humanity and human rights violations. The principle states that States are responsible for ensuring the security of their people and protecting them against crimes practiced against humanity, but when the State fails to assume this responsibility, the international community can intervene to protect civilians by peaceful or military means (Damboeck, 2012).

The Syrian issue presents a model consistent with humanitarian intervention under the principle of 
"responsibility to protect". The Syrian government has systematically and indiscriminately attacked civilians, creating a crime against humanity (Hattab, 2019).

Despite efforts by the international community to put an end to the violence in Syria through peaceful measures such as intensified diplomacy, economic sanctions and even waving the stick of international law, they failed to stop the killing (Tokmajyan, 2015). Moreover, the Syrian regime ignored the Arab-International Joint Ceasefire Agreement and attacked civilians in the presence of international observers in 2012. In August 2013, the Syrian regime launched an atrocious attack using a weapon of mass destruction (internationally banned sarin gas) in the eastern and western parts of Damascus, killing 1,500 people, mostly women and children, who died of suffocation while sleeping in their homes (Feinstein \& Starr, 2015).

According to the principle of "responsibility to protect", an alliance of states or regional organizations can legitimately intervene in Syria with or without authorization from the Security Council (Damboeck, 2012). Especially, Intervention in Syria in this manner may be the best hope for the international community to avoid further humanitarian disasters, and it will be in harmony with international law and the UN Charter (Hattab, 2019).

In 2009, UN Secretary-General Ban Ki-moon described the principle of "responsibility to protect" through three basic rules: (Bellamy, 2005; Odeyemi, 2015):

First, every State must take responsibility to protect its people from genocide, war crimes and ethnic cleansing.

Second, it is the responsibility of the international community to assist States in fulfilling their obligations under rule 1.

Third, if the state clearly fails to protect its people, the international community must take responsibility to act with immediate and decisive deal, in accordance with Chapter VI, VII and VIII of the Charter of the United Nations, using measures ranging from the use of peaceful to military means.

In some emergent situations, it is allowed for international alliances to intervene legitimately to stop serious violations of international law without the prior approval of the Security Council.

Feinstein and Starr (2015) confirmed that when peaceful actions fail to end a crisis that poses a threat to world peace and security, the Security Council can authorize Member States to use force to protect civilians under Chapter VII and Article 42 of the Charter of the United Nations. Since peaceful options for the protection of civilians have been exhausted, it is the duty of the international community to consider stricter measures at a time when it seems impossible to obtain the authorization of the Security Council to do so politically, and owing to the given persistent circumstances, the international community has the right to take action under the principle of "responsibility to protect" to protect the Syrian people away from the veto (Kent, 2014).

Typically, Security Council resolutions use the words "all necessary measures" to allow the international community to use force. Such these measures include the blockade and other operations by land, sea, or air, to establish safe areas or no-fly zones, to protect the human right in the safe life of those at risk, and to allow the use of all necessary processes or all necessary means to protect civilians (Anderson, 2011).

As a result, the Security Council adopted resolution 733, which allowed the establishment of a military embargo under Chapter VII to restore security and stability, and resolution 794, which allowed the use of all necessary means and the utmost speed to establish a security environment during which humanitarian relief operations under Chapter VII can be achieved (Odeyemi, 2015).

According to the Official Records of the General Assembly, Sixty-sixth Session (2012), The Security Council adopted resolution 2059 (2012) at its 6812th meeting, on 20 July 2012 commending the efforts of the United Nations for surveillance in Syria. Also, the General Assembly on 16 February 2012 adopted resolution 66/253 related to the situation in the Syrian Arab Republic recalling its resolution 66/176 dated 19 December 2011 and the resolutions of the Human Rights Council dated 29 April 2011 and 17/1 dated 23 August 2011 and 18/1 dated in 2 December 2011 in which The General Assembly expresses its deep concern at the deterioration of the situation in the Syrian Arab Republic, in particular the continuing violation by the Syrian authorities of human rights and the use of violence against the population.

In fact, Syria crisis initiated in 2011 changed the world's views toward UN and converted the balance in the concept of UN strategies and objectives. Gisslen (2018) Argued that many different sides in discussion of the legality of humanitarian intervention reject some fundamental aspects within international law, like how international law justify with changing time, and how resolutions and treaties can be interpreted, etc. According to Gisslen, such these questions and like others are still debated, especially with the Syrian civil war. According 
to human rights agencies, Assad- led regime practiced stressful human rights violations against the civilians, and based on intense discussions, this disaster entails legality of humanitarian interventions (Burckle, 2018). But the consensus by the international law community was that the humanitarian intervention is considered as illegal.

Definitely, in case of Syria, the civil war has resulted in seven million internally displaced citizens, three million Syrian refugees, and more than 250,000 deaths (Kent, 2014). Despite These Humanitarian disasters realized the above conditions under criteria of "just cause", the Syrian civil war continued until the end of 2018 leading to more humanitarian aggravation of bad situations. By contrast, Libya witnessed less humanitarian disasters compared with Syria, but security council issued its decision of immediate military intervention supported with "no- fly- zone", which helped Libyan rebels to overthrow the preceding president "Muammar Gaddafi" and the capital "Tripoli" had fell with the grip of the rebels (Taleb, Ratiu, \& Molz, 2017). This corresponding behavior by the UN was controversial at many scholars about the compelling duty by UN towards the humanitarian disasters.

The principle of "responsibility to protect" has been developed to achieve consensus in favor of international action to prevent or stop mass atrocities. However, it has failed to do so in Syria. Worse still, the implicit support provided by the principle of intervention without the consent of the United Nations has contributed to the paralysis of the international community to respond effectively to the human rights crisis in Syria (Thakur, 2013).

Consequently, the paralysis of UN in Syrian crisis indicates that UN must reconsider its strategies so that it can expand its authorities to provide more security to the citizens who are exposed to the danger of their states (Odeyemi, 2015). This means that rebuilding international consensus to act against atrocities will require rethinking about the "responsibility to protect" and the phantom military solutions that it provides. Until now, and after all crimes and disasters practiced by the Syrian regime represented by its president " AL-Assad" , the civil war against Syrian citizens nearly ended and no effective resolution has been taken by the UN against the accustomed repression and oppressions.

\subsubsection{Second: Humanitarian Intervention in Somalia}

The international military intervention in the Somali crisis is an important model for evaluating the legitimacy of intervention in the internal affairs of states for humanitarian considerations without the consent of the State concerned, Whether this intervention was done by the United Nations as an international organization or by some countries that have officially entered Somalia under the umbrella of UN without direct and effective conduct by these countries to UN in terms of leadership's intervention or the conduct of the military operations and the objectives prepared for them (Odeyemi, 2015).

The overthrow of the "Siad Bari" regime on 21 November 1992 led to the spread of chaos in Somalia due to the conflict of 14 movements, the most important of which were the Somalia Unified Conference led by Mohamed "Farah Aidid" and the National Alliance for the Salvation of Somalia led by "Ali Mahdi" (Wennsland, 2013). Additionally, the North has announced the establishment of an independent state. The Center for Strategic Studies in London revealed that since the outbreak of the war in Somalia in 1991 - until 1994, the war had killed about 75 thousand Somalis (Seybolt, 2008).

These complicated conditions have compelled the Interim Administrator of the UN Operation in Somalia (UNOSOM) to appeal to the Security Council for essential intervention to provide humanitarian assistance in a letter in 20 September 1991, preceded by a letter from President "Abdou Diouf" of the Islamic Conference to the Security Council, on which the Security Council issued the resolution of 733 in 23 January 1992 (Ulriksen, 2010).

Resolution 733 contained a set of provisions that emphasized the need to immediate humanitarian assistance by the United Nations and its specialized agencies to Somalis with the appointment of a coordinator to oversee their distribution. This decision, however, did not meet the goals for which it was initiated, which exacerbated the tragedies for Somalia civilians in a manner that threatened the international peace and security (kent, 2014). This reason prompted the Security Council to issue another resolution bearing the number of 571 in 24 April 1992 including the formation of an international security force for purpose of ensuing humanitarian access to Somalia, followed by resolution of 775 in 28 August 199 stressing the need to protect the port of Mogadishu and escort humanitarian convoys until the arrival of humanitarian assistance to the distribution centers accompanied with protection (Bellamy \& Williams, 2006).

The failure of the United Nation forces to achieve their objectives because of their low number (estimated at 500 blue-helmeted troops) made the Secretary-General declares that the operation had not met its purposes 
(Lachenmann \& Wolfrum, 2017). Then, the Security Council authorized international intervention in Somalia under resolution 794 in 3 December/ I994, expressing its concern about the magnitude of the humanitarian tragedy in Somalia, which constitutes a threat to international peace and security (Philip, 2005). Accordingly, military forces have been sent to Somalia to ensure the arrival of humanitarian assistance in the process of restoring hope.

International jurisprudence agrees that the Security Council intervened late in Somalia, and it did not directly lead UN forces, but entrusted it to the American United States. In addition, the Security Council did not directly supervise the military intervention in Somalia, but deviated it to the United States, which invested somali situation for realizing its political purposes. The United States did not tend to food distribution and reconciliation achievement among the conflicting parties, instead it pursued "Mohammad Farah" and practiced killing of Somalian people, reason that led great numbers of Somalis to take refuge the neighboring countries, such as to Ethiopia and Kenya (Wennsland, 2013).

It is an undeniable fact that millions of people are still at the mercy of civil wars, insurgency, and state repression. The important issue here is not to make the world safe for the big Powers, and trample on the sovereign rights of small States, but to provide practical protection to ordinary people whose lives are at risk because their States are unwilling or unable to protect them (Flott, 2008). In the same context, Novosseloff (2000) Confirmed that since 1995, UN has become an organization that keeps order, rather than keeps peace in the world. He added that most recent peacekeeping operations in fact were considered as police missions that aimed to rebuild administrative structures of a state. He emphasized that following the UN failure in Rwanda, Bosnia, and Somalia because of the loss of strategy and will, many states no longer trust UN anymore and prefer to behave via regional organizations or multinational coalitions.

\subsubsection{Third, Role of the United Nations' Interim Administration Mission in Kosovo}

The Republic of Kosovo is located in the Balkan region of southern Europe with a population of about 2 million. 92\% of the population is Albanian. 5\% Serbs, and the rest are different races. It was part of the Ottoman Empire for five centuries. After the first Balkan War of 191 the Kingdom of Serbia and Montenegro shared the territory of Kosovo (Jura, 2013). After the Second World War, specifically in 1946, the province of Kosovo was annexed to the Federal Republic of Yugoslavia, and after the regime of President "Joseph Bros. Tito", and according to the 1947 Constitution, Kosovo lived in the framework of the Union of Yugoslav Republics until the late 1970s (Hehir, 2008).

In 1989, Serbian President "Slobodan Milosevic" ended the autonomy enjoyed by Kosovo Albanians and governed the province with iron and fire using violent repressive police tactics. The people of Kosovo organized themselves to face the persecution they were subjected to after the abolition of self-rule. Their organization was more national in nature than religious, led by the Albanian Democratic Union Party, which was headed by the writer and professor "Ibrahim Rugova" who had taken the national struggle as his peaceful and political approach (Bellamy, 2005).

On May 24, 199 Albanians elected "Ibrahim Rugova" as president of their Republic, which they called "the Republic of Kosovo", but Serbians did not recognize it. However, Ibrahim Rugova, known for his peaceful approach, tried to win the international community's sympathy and recognition of the Republic of Kosovo but did not succeed, therefore the Albanian youth constituted military cells called "Kosovo Liberation Army" (KLA) (Damboeck, 2012). On July 1995, the people of Kosovo held a general referendum which resulted in the desire of the majority to secede from Serbia and establish an independent republic. In September of the same year, the Albanians organized a massive strike similar to the civil disobedience of Serbia (Wheeler, 2001).

The tragic actions in 1998 drew the world's attention to the danger of the situation in Kosovo, where the KLA entered into conflict with the Serbian army, and the latter committed brutal massacres against Albanian civilians forcing the international community to act emergently (Bellamy, 2005). As a stringent and sound reaction, In March 1999, The North Atlantic Treaty Organization (NATO) launched air strikes against Serbia, forcing its president "Milosevic" to withdraw from Kosovo, and as a result Belgrade lost effective control of the territory, which was placed under the protection of the United Nations and NATO, which spread about 17 thousand soldiers in that recovered territory (Hehir, 2008). On the final status of Kosovo, Negotiations were held between Serbs and Kosovar Albanians, at the end of which "Martti Ahtisaari", commissioned by the United Nations to prepare a final status for the Territory, set a plan of independence under international supervision supported by the Americans and Europeans (Odeyemi, 2015).

a. The Establishment of the Mission in Kosovo 
After the settlement of disputes between the warring parties (the Albanians and the Serbs), Kosovo had not the potential to independently rebuild itself, reconstruct its economy, and reform durable institutional regulations and policies. In this manner, United Nation Mission in Kosovo (UNMIK) manifested its prominent role to help Kosovo to handle all its situations. The UNMIK helped Kosovo to make long strides in establishing and consolidating democratic, interim, and autonomy institutions which are accountable for laying the foundations of a sound economy (Charlesworth, 2002; Earnest, 2015). Mustafa (1999) Summarized project development and the reconstruction complex dynamics in Kosovo by arguing that international agencies were working in parallel in different areas on the same issues at the same time without involving the local community.

according to Independent International Commission on Kosovo (IICK, 2000), The Mission was established in June 1999 because of serious human rights violations, clashes between the Kosovo Army and the Yugoslav forces, and the mass deportation of Kosovo Albanians. The Security Council, by its resolution 1244 of 10 June 1999 authorized Member States to establish an international security presence in Kosovo to prevent hostile acts, to disarm the Kosovo army, and to facilitate the return of refugees. It also requested the Secretary-General to establish an international civilian presence in Kosovo that is known as the United Nations Interim Administration Mission in Kosovo (UNMIK), to provide an interim administration for Kosovo in which people would enjoy autonomy and self-rule. Accordingly, The Yugoslav forces withdrew, NATO suspended its bombardment, and multinational forces of 50,000 troops led by NATO reached Kosovo to assure security (Krain, 2005).

The Mission immediately established a presence in the field. Its task was complex and vast in scope to an unprecedented degree. The security council mandated the UN Mission to the territory of Kosovo, including all legislative, executive and judicial authorities, and requested the Mission to perform basic civilian administrative functions, promote the establishment of substantial autonomy and self-government in Kosovo, facilitate a political process to determine Kosovo's future status, and Coordinate the relief aid as well as that introduced in cases of disasters with all international agencies, Support reconstruction of the main infrastructure, maintain civil law and order, promote human rights, safeguard return of all refugees, and displace people to their homes securely (Earnest, 2015).

\section{b. The Basic Pillars of the Mission in Kosovo}

In the first of its kind, UNMIK first brought together four "pillars" under the leadership of the United Nations (Todd, 2002):

Pillar 1 - humanitarian assistance, led by the Office of the United Nations High Commissioner for Refugees (UNHCR).

Pillar II - Civil Administration, within the framework of the United Nations.

Pillar III - Democratic transformation and institution-building, led by the Organization for Security and Cooperation in Europe (OSCE).

And Pillar IV - reconstruction and economic development, administered by the European Union.

Following the end of the emergency phase, the work of United Nations High Commissioner for Refugees (UNHCR) work was gradually liquidated under Pillar One at the end of June 2000 after the return of the majority of the refugees who fled during the war (Novosseloff, 2000). The first pillar has been responsible for the tasks of achieving the rule of law from then on. The Special Representative of the Secretary-General, as the largest international civilian official in Kosovo, is responsible for the work of these pillars and for supporting the political process that aimed at determining Kosovo's future status (Valeza, 2015).

In the years that followed, the United Nations-led Interim Administration with the support of its key implementing partners, including the European Union, the Organization for Security and Cooperation in Europe, and United Nations agencies with their funds and programs, helped Kosovo to make long strides in establishing and strengthening self-governance as well as democracy undergone to accountability, in addition to laying the foundations for a sound economy (Todd, 2002). However, the achievement of full reconciliation and full integration among communities in Kosovo remains a challenge.

The Organization of Security and Cooperation in Europe (OSCE) beside the European Union Mission for the Rule of Law in Kosovo continue to play their important roles within the framework of Security Council resolution 1244 (Novosseloff, 2000). Moreover, The United Nations Interim Administration Mission in Kosovo (UNIAMIK) and the Organization of Security and Cooperation in Europe (OSCE) in Kosovo are exchanging information on a regular basis, particularly on political and security developments (Todd, 2002). 


\section{Conclusion}

The aim of this paper has been to identify extent the humanitarian interventions were effective to solve some complex national crises, and failed to do so in some others. Three main national crises were taken in consideration of the current study; Syrian crisis, Somalian crisis, and Kosovar crisis. Although the three cases had occurred in similar manner, each one of them was dealt by UN, through humanitarian intervention, independently and inconsistently. The paper's analysis of the humanitarian intervention concluded that UN had treated some national crises successfully and fairly, such as Kosovo's situation, and Libyan situation, but it had got failure in other cases, such as Syrian situation. Moreover, in some crucial situations, UN commissioned the responsibility to other political powers, such as USA in Somalia that behaved independently in that country to achieve its own interests. Ultimately, according to the UN contradictory attitudes about the crucial national challenges, it should devote huge efforts toward rethinking of its strategies and policies that enable it to treat all crucial situations throughout the world fairly and decisively.

\section{Recommendations}

According to the analysis of the humanitarian intervention by the United Nation in the three cases (Syria, Somalia, and Kosovo) of civil war and violation of human rights, the current study can manifest the following recommendations, in which UN should:

- Strive toward rethinking of its strategies and policies to be more effective, reactive, and decisive in dealing with and treating the crucial national issues worldwide.

- Need to reconstruct its principles to be more cooperative among all members without bias to some powerful states.

- $\quad$ Not to slow down in making decisions in difficult humanitarian crises such as the Syrian crisis, move, and react in the suitable time where the targeted issue can be solved properly without threatening to the human life.

- Establish clear rules, procedures and standards to determine whether, when and how to intervene.

- Prove the legitimacy of military intervention when necessary and after all other approaches get failed.

- Ensure that the military intervention is carried out when it occurs for the proposed purposes only and that it is effective and motivated by the proper care to minimize the resulting human losses and damage.

- Help to remove the causes of conflict wherever possible, while increasing the prospects for a durable and sustainable peace.

\section{References}

Anderson, L. (2011). Demystifying the Arab spring: parsing the differences between Tunisia, Egypt, and Libya. Foreign Affairs, $\quad 90(3), \quad 2-7 . \quad$ Retrieved $\quad$ from http://pages.ucsd.edu/ phsmith/documents/Anderson-Demystifying-the-Arab-Spring.pdf

Annan, K. (2000, February 15). Secretary- General of the United Nations Addresses International Peace Academy Seminar on "The Responsibility to Protect". Retrieved from www.un.org/News/Press/docs/2002/sgsm8125.doc.htm

Bellamy, A. J., \& Williams, P. D. (2006). The UN Security Council and the question of humanitarian intervention in Darfur. Journal of Military Ethics, 5(2), 144-60. https://doi.org/10.1080/15027570600707680

Bellamy. A. (2005). The three pillars of the responsibility to protect. Retrieved from http://www.cries.org/wp-content/uploads/2015/09/006-bellamy.pdf

Bertschinger, A. (2016). Humanitarian Intervention: An inviable concept. Published thesis, King's College, London. https://doi: 10.13140/rg.2.2.12366.87364.

Burckle, F. M. (2018). United Nations charter, chapter VII, article 43: Now or Never. Disaster Medicine and Public Health Preparedness, 1-8. Retrieved from https://doi.org/10.1017/dmp.2018.43

Cavandoli, S., \& Odello, M. (2011). Emerging areas of human rights in the 21st century: The role of the universal declaration of human rights. UK: Routledge-Cavendish.

Charlesworth, H. (2002). International law: a discipline of crisis. The Modern Law Review, 65(3), 377-392. Retrieved from https://www.jstor.org/stable/1097579?seq=1\#page_scan_tab_contents

Damboeck, J. (2012). Humanitarian interventions: western imperialism or a responsibility to protect: An analysis of the humanitarian interventions in Darfur. Multicultural Education \& Technology Journal, 6(4), 287-300. https://doi.org/10.1108/17504971211279536 
Earnest, J. (2015). Post-conflict reconstruction - a case study in Kosovo: The complexity of planning and implementing infrastructure projects. International Journal of Emergency Services, 4(1), 103-128. https://doi.org/10.1108/IJES-02-2015-0009

Feinstein, A., \& Starr, S. (2015). Civil War in Syria: the psychological effects on journalists. Journal of Aggression, Conflict and Peace Research, 7(1), 57-64. https://doi.org/10.1108/JACPR-04-2014.

Flott, D. (2008). The Responsibility to Protect: Sovereignty, Political Will and Capabilities. European security Review, $39 . \quad$ Retrieved from https://www.researchgate.net/publication/216768988_The_Responsibility_to_Protect_Sovereignty_Political _Will_and_Capabilities

Foley, C. (2013). The evolving legitimacy of humanitarian interventions. International Journal on Human Rights, 10 (19). Retrieved from https://ssrn.com/abstract $=2445667$

Fontane, J., \& Geslin, A. (2008). Political economy of the humanitarian actions. In J. Fontanel, \& M. Chatterji (Eds.), War, Peace and Security (Contributions to Conflict Management, Peace Economics and Development) (pp. 215 - 233). Emerald Group Publishing Limited.

Gary, J. (2008). Freedoms Battle: The Origins of Humanitarian Intervention. New York: Alfred A. Knopf.

General Assembly. (2012). Resolution adopted by the General Assembly, sixty-sixth session (66/253): The situation in the Syrian Arab Republic. Retrieved from https://www.securitycouncilreport.org/atf/cf/\%7B65BFCF9B-6D27-4E9C-8CD3-CF6E4FF96FF9\%7D/a_re s_66_253_b.pdf

Gisslen, M. (2018). Humanitarian Intervention in history: An Analysis of the historical evolution of the doctrine. Retrieved from https://www.researchgate.net/publication/314260606

Hattab, S. (2019). Deepening democracy or stabilization?: European neighborhood policy (ENP) and the "Arab spring". Review of Economics and Political Science, 4(1), 20-37. https:// doi.org/10.1108/REPS-10-2018-009

Hehir, A. (2008). Humanitarian intervention after Kosovo: Iraq, Darfur and the Record of Global Civil Society. New York, NY: Palgrave Macmillan.

ICISS. (2001). "The responsibility to protect", Report of the international commission on intervention and state sovereignty. Retrieved from International Development Research Center. Retrieved from http://responsibilitytoprotect.org/ICISS\%20Report. pdf

Independent International Commission on Kosovo (IICK). (2000). The Kosovo report: Conflict, international response, lessons learned. Oxford University Press, U.S.A.

Janzekovic, J., \& Silander, S. (2013). Responsibility to protect and prevent: Principles, promises and practicalities. London. Anthem Press.

Joseph, H. (2011). Middle East security report 2: The struggle for Syria in 2011. Retrieved from http://www.understandingwar.org/sites/default/files/Struggle_For_Syria.pdf

Jura, C. (2013). Kosovo - history and actuality. International Journal of Juridical Sciences, 3, 78-84.

Kent, G. (2014). Rights and obligations in international humanitarian assistance. Disaster Prevention and Management, 23(3), 214-221. https://doi.org/10.1108/DPM-07-2013-0122

Krain, M. (2005). International intervention and the severity of genocides and politicides. International Studies Quarterly, 49(3), 363-388. https://doi.org/10.1111/j.1468-2478.2005.00369.x

Lachenmann, F., \& Wolfrum, R. (2017). Max planck yearbook of United Nations law. Netherlands: Brill Academic Publishers.

Mustafa, M. (1999). Reconstruction experiences and policies: the case of Kosova, LSE-WIIW Conference "Reconstruction and Integration in Southeast Europe: Economic Aspects", United Nations Economic Commission for Europe, Geneva, 12-13 November. Vienna.

Novosseloff, A. (2000). Revitalizing the United Nations: Anticipation and prevention as primary goals. Foresight, 2(1), 95-111. https://doi.org/10.1108/14636680010802500

Odeyemi, C. (2015). The responsibility to protect (R2P) in Libya and Syria: Exploration of the BRICS Role, 2011-2014. Journal of Global Responsibility, 6(2), 229-245. https:// doi.org/10.1108/JGR-04-2015-000 
Philip, V. (2005). Max plank yearbook of United Nations law: Somalia - A very special case. Netherlands: Koninklijke Brill.

Seybolt, T. (2008). Humanitarian military Intervention: The conditions for success and failure. Oxford University Press: Norfolk.

Taleb, A., Ratiu, R., \& Molz, R. (2017). Corporate diplomacy and institutional upheaval in host countries: The 'Arab Spring' experience of two canadian multinationals in Egypt. International Business Diplomacy, 241-264.

Thakur, R. (2013). R2P after Libya and Syria: Engaging emerging powers. The Washington Quarterly, 36(2), 61-76. http://dx.doi.org/10.1080/0163660X.2013.791082

Todd, M. (2002). Communicating economic reform: Experiences from the EU Pillar of UNMIK. Journal of public affairs, 2(3). https://doi.org/10.1002/pa.108

Tokmajyan, A. (2015). Militarization of the Syrian revolution: was this the wrong choice?. Journal of Aggression, Conflict and Peace Research, 7(2), 101-111. https://doi.org/10.1108/JACPR-03-2014-0011

Tufekci, O. (2018). Can War Ever Be Ethical? Perspectives on just war theory and the humanitarian intervention concept. Atatürk University Journal Of Economics And Administrative Sciences, 32(4). Retrieved from https://www.researchgate.net/publication/328190969_Can_War_Ever_Be_Ethical_Perspectives_On_Just_ War_Theory_And_The_Humanitarian_Intervention_Concept

Ulriksen, S. (2010). Webs of war: Managing regional conflict formations in West Africa and Central Africa. In K. B. Harpviken (Ed.), Troubled Regions and Failing States: The Clustering and Contagion of Armed Conflicts (Comparative Social Research, Volume 2, pp. 355-380). Emerald Group Publishing Limited.

Valeza, U. (2015). An empirical study of the United Nations Peacekeeping mission in a post-conflict country: The Kosovo case. Balkan Social Science Review, 6, 201-221. Retrieved from http://js.ugd.edu.mk/index.php/BSSR/article/view/1259

Wennsland, M. (2013).The USA involvement in Somalia in the post- cold war years: An illustration of the tension between interests and principles In America foreign policy. Published Dissertation, University of ISLO.

Wheeler, N. J. (2001). Legitimating humanitarian intervention: principles and procedures. Melbourne Journal of International Law, 2(2), 550-67. $\quad$ Retrieved https://law.unimelb.edu.au/_data/assets/pdf_file/0009/1680228/Wheeler.pdf

\section{Copyrights}

Copyright for this article is retained by the author(s), with first publication rights granted to the journal.

This is an open-access article distributed under the terms and conditions of the Creative Commons Attribution license (http://creativecommons.org/licenses/by/4.0/). 